\title{
FAKTOR PENENTU KUALITAS LAYANAN DAN MINAT UNTUK MELANJUTKAN PENGGUNAAN SISTEM PELAPORAN ONLINE
}

\author{
Santirianingrum Soebandhi, Intan Nur Aini, \& Agus Baktiono \\ Universitas Narotama, Indonesia \\ Email: santirianingrum@narotama.ac.id
}

\begin{abstract}
Abstrak: Faktor Penentu Kualitas Layanan dan Minat untuk Melanjutkan Penggunaan Sistem Pelaporan Online. Penelitian ini bertujuan untuk menganalisis pengaruh perceived usefulness, perceived ease of use, kenyamanan, dan keamanan terhadap kualitas layanan dan minat untuk melanjutkan menggunakan SIPP online di BPJS Ketenagakerjaan. Penelitian ini menggunakan metode survei online kepada 50 perusahaan peserta BPJS Ketenagakerjaan dengan segmentasi Platinum dan Gold. Kuesioner online diisi oleh Kepala Bagian Sumber Daya Manusia. Data dianalisis dengan menggunakan PLS-SEM. Penelitian ini menemukan bahwa kualitas layanan secara signifikan dipengaruhi oleh perceived ease of use dan kenyamanan, sedangkan minat melanjutkan penggunaan SIPP online hanya dipengaruhi oleh perceived usefulness.
\end{abstract}

Kata Kunci: minat melanjutkan penggunaan, kualitas layanan, sistem pelaporan online

\begin{abstract}
Determinants of Service Quality and Continuance Intention to Use Online Reporting System. This study aims to analyze the effect of perceived usefulness, perceived ease of use, convenience, and security towards service quality and continuance intention to use SIPP online at BPJS Employment. This study uses online survey method to 50 companies participating in BPJS Employment with Platinum and Gold segmentation. The online questionnaire was filled by the head of Human Resources Department. Data were analyzed using PLS-SEM. The results show that service quality was significantly influenced by perceived ease of use and convenience, while continuance intention to use SIPP online was only influenced by perceived usefulness.
\end{abstract}

Keywords: continuance intention, service quality, online reporting system

\section{PENDAHULUAN}

Penggunaan teknologi untuk mempermudah layanan kepada pelanggan saat ini banyak digunakan pada perusahaan, terutama perusahaan yang bergerak di bidang jasa. BPJS Ketenagakerjaan merupakan salah satu perusahaan yang bergerak di bidang jasa layanan publik yang selalu mengembangkan kualitas layanannya untuk meningkatkan kepuasan pelanggan. Penggunaan teknologi tidak luput dari perhatian BPJS Ketenagakerjaan. Aplikasi berbasis website pun dibuat oleh BPJS Ketenagakerjaan untuk mempermudah dan mempercepat layanan kepada pelanggan, salah satunya adalah Sistem Informasi Pelaporan Peserta (SIPP) online yang dapat digunakan untuk melakukan mutasi data dan upah tenaga kerja secara online.

Sesuai dengan Peraturan Pemerintah Republik Indonesia Nomor 86 Tahun 2013 Pasal 3 disebutkan bahwa pemberi kerja wajib melakukan pelaporan perubahan data dan upah paling lambat 7 hari sejak 
terjadinya perubahan. SIPP online merupakan aplikasi yang dibuat oleh BPJS Ketenagakerjaan untuk mempermudah pelaporan data dan upah tenaga kerja di setiap perusahaan, sehingga perusahaan tidak perlu melakukan pelaporan secara manual karena SIPP online bisa diakses di manapun dan kapan pun. Dari data Sistem Informasi Jaminan Sosial Tenaga Kerja (SIJSTK) diketahui bahwa pada Desember 2015 jumlah pengguna SIPP online sebesar 84,5\%, namun data pada Maret 2016 menunjukkan penurunan jumlah pengguna yaitu sebesar $79,65 \%$, di mana $4,85 \%$ perusahaan kembali menggunakan pelaporan manual (BPJS Ketenagakerjaan, 2016).

Memotivasi perusahaan untuk menggunakan layanan mandiri secara online ini dapat menjadi tantangan karena membutuhkan kesediaan mereka untuk mempelajari sistem baru dan sumber tambahan untuk menggunakannya (Curran \& Meuter, 2005; Lin \& Filieri, 2015). Sementara itu kualitas layanan juga merupakan faktor penting yang menentukan adopsi dan minat untuk melanjutkan penggunaan sistem (Jiang \& Ji, 2014). Oleh karena itu, penelitian ini bertujuan untuk mengetahui pengaruh dari faktor-faktor penentu kualitas layanan dan minat untuk melanjutkan penggunaan SIPP online BPJS Ketenagakerjaan sehingga BPJS Ketenagakerjaan dapat melakukan evaluasi terhadap aplikasi yang telah dibuat agar perusahaan akan terus menggunakan aplikasi tersebut.

Minat untuk menggunakan atau melanjutkan penggunaan kembali suatu sistem (continuance intention) merupakan luaran jangka panjang yang penting dan merupakan indikator kesuksesan suatu sistem (Bhattacherjee \& Premkumar, 2004; Hu, Brown, Thong, Chan, \& Tam, 2009; Lee \& Chen, 2014; Wu, Chen, Sheng, \& Wang, 2009). Kegunaan yang dirasakan mengarahkan pengguna pada kepuasan akan kualitas layanan sistem yang menyebabkan pelanggan berminat melanjutkan penggunaan sistem tersebut. Kualitas layanan merupakan perbandingan antara layanan yang diharapkan dengan layanan yang diterima oleh konsumen (Parasuraman, Zeithaml, \& Berry, 1988). Penelitian terdahulu telah mengkonfirmasi bahwa kualitas layanan merupakan prediktor penting karena berpotensi untuk mempengaruhi perilaku konsumen di masa depan dan dapat digunakan untuk mengevaluasi kesuksesan suatu sistem (Rai, Lang, \& Welker, 2002; Zeithaml, Berry, \& Parasuraman, 1996; Zhao, Lu, Zhang, \& Chau, 2012). Dalam penelitian ini digunakan lima dimensi kualitas layanan yang dirumuskan oleh Parasuraman et al. (1988) yang terdiri dari reliability (kemampuan untuk melakukan layanan yang dijanjikan secara andal dan akurat), assurance (pengetahuan, kesopanan, dan kemampuan karyawan untuk menyampaikan kepercayaan dan keyakinan), tangibles (fasilitas fisik, peralatan, dan penampilan personil), empathy (peduli, perhatian individual terhadap pelanggan), dan responsiveness (kesediaan untuk membantu pelanggan, dan memberikan layanan yang cepat).

Penerimaan seseorang terhadap teknologi dapat dijelaskan dan diprediksi dengan menggunakan Technology Acceptance Model (TAM) (Davis, 1985). Dalam riset perilaku konsumen, TAM 
terbukti dapat digunakan untuk memprediksi minat dan penggunaan suatu sistem (Vijayasarathy, 2004) serta banyak diuji sebagai prediktor dari kualitas layanan (Hu et al., 2009). Menurut Davis (1985), penerimaan teknologi informasi dipengaruhi oleh sikap penggunaan yang menjadi keyakinan utama, di mana sikap penggunaan teknologi informasi tersebut dipengaruhi oleh dua faktor, yaitu perceived usefulness (PU) dan perceived ease of use (PEOU). PU yaitu sejauh mana kepercayaan seseorang bahwa menggunakan sistem tertentu akan meningkatkan kinerja pekerjaannya. Hasil penelitian yang dilakukan oleh $\mathrm{Hu}$, et al. (2009) menunjukkan bahwa PU berpengaruh secara positif terhadap kualitas layanan. PU juga merupakan indikator minat untuk melanjutkan, sebab manusia cenderung untuk selalu mengejar manfaat yang didapatkan (Bhattacherjee, 2001). Hasil penelitian yang dilakukan oleh Bhattacherjee (2001) dan Lee \& Chen (2014) menunjukkan bahwa PU berpengaruh secara positif terhadap minat untuk melanjutkan sistem informasi. Sehingga hipotesis yang kami ajukan adalah sebagai berikut:

H1.Perceived usefulness berpengaruh signifikan terhadap kualitas layanan SIPP online

H2. Perceived usefulness berpengaruh signifikan terhadap minat untuk melanjutkan menggunakan SIPP online

Perceived ease of use (PEOU) adalah sejauh mana kepercayaan seseorang bahwa menggunakan sistem tertentu akan membebaskan mereka dari upaya fisik dan mental. Jika PEOU sistem online rendah, pelanggan mungkin tidak memiliki pengalaman layanan yang positif, sehingga kedepannya bisa menghambat penggunaan sistem online tersebut (Hu et al., 2009). Hidayat-ur-rehman, Mokhtar, \& Katan (2016) menyatakan jika sistem online mudah digunakan, maka akan membawa dampak yang positif terhadap penggunaan sistem online. Pada akhirnya pengguna yang merasa puas akan sistem tersebut akan meningkat dan menimbulkan minat melanjutkan penggunaan. Hasil penelitian yang dilakukan oleh Hu, et al. (2009) menunjukkan bahwa PEOU berpengaruh secara positif terhadap kualitas layanan dan dapat digunakan untuk menjelaskan minat melanjutkan penggunaan sistem setelah mereka mencoba sistem tersebut (Lin \& Filieri, 2015). Sehingga kami mengajukan hipotesis sebagai berikut:

H3. Perceived ease of use berpengaruh signifikan terhadap kualitas layanan SIPP online

H4. Perceived ease of use berpengaruh signifikan terhadap minat untuk melanjutkan menggunakan SIPP online

Selain PU dan PEOU, fitur layanan seperti kenyamanan (convenience) dan keamanan (security) merupakan dua karakteristik penting yang dapat mempengaruhi penggunaan layanan online (Ahuja, Gupta, \& Raman, 2003; Hu et al., 2009; Zeithaml, Parasuraman, \& Malhotra, 2002). Kenyamanan merupakan persepsi waktu dan usaha konsumen terkait pembelian atau penggunaan layanan (Berry, Seiders, \& Grewal, 2002; Chang, Chen, Pang, Chen, \& Yen, 2013). Kenyamanan juga didefinisikan sebagai waktu dan usaha yang diperlukan untuk menyelesaikan suatu pekerjaan (Collier \& Kimes, 2012). Beberapa penelitian telah menunjukkan pentingnya kenyamanan dalam mempengaruhi penggunaan layanan 
online, sehingga terbentuk persepsi kualitas layanan (Berry et al., 2002; Zhang \& Prybutok, 2005). Kenyamanan juga berpengaruh pada minat untuk melanjutkan penggunaan sistem. Kenyamanan merupakan pertimbangan utama dalam keputusan konsumen untuk menggunakan layanan yang diberikan meggunakan saluran online. Jika seseorang merasa nyaman untuk menggunakan sistem online maka mereka akan memiliki minat untuk melanjutkan sistem online tersebut (Torkzadeh \& Dhillon, 2002). Sehingga hipotesis yang kami ajukan adalah:

H5. Kenyamanan berpengaruh signifikan terhadap kualitas layanan SIPP online

H6. Kenyamanan berpengaruh secara signifikan terhadap minat untuk melanjutkan menggunakan SIPP online

Keamanan merupakan perasaan aman dan percaya terhadap situs, di mana layanan online tersebut akan menjaga informasi rahasia, pribadi, dan aman dari akses yang tidak sah (Zeithaml et al., 2002). Keamanan berkaitan erat dengan risiko dan kepercayaan, di mana resiko dan kepercayaan merupakan dampak langsung dari keamanan. Risiko dan kepercayaan mempengaruhi keamanan dan akhirnya mempengaruhi kualitas layanan ( $\mathrm{Hu}$ et al., 2009). Hasil penelitian yang dilakukan oleh Jarvenpaa \& Todd (1996) tentang keputusan belanja konsumen melalui Web menunjukkan bahwa risiko merupakan pertimbangan terhadap kualitas layanan yang dirasakan oleh pelanggan. Sedangkan penelitian yang dilakukan oleh Miyazaki \& Fernandez (2001) menunjukkan bahwa keamanan menjadi perhatian penting dari konsumen, di mana keamanan telah terbukti menghambat pembelian online dan penggunaan layanan. Sehingga kami mengajukan hipotesis sebagai berikut:

H7. Keamanan berpengaruh signifikan terhadap kualitas layanan SIPP online H8. Keamanan berpengaruh secara signifikan terhadap minat untuk melanjutkan menggunakan SIPP online

Kegunaan yang dirasakan setelah menggunakan suatu sistem dapat mengarahkan pengguna pada kepuasan akan kualitas layanan sistem yang menyebabkan mereka berminat untuk melanjutkan penggunaan sistem. Minat adalah variabel dependen utama yang menarik untuk diteliti pada banyak ilmu informasi dan perilaku konsumen (Hu et al., 2009). Hasil penelitian yang dilakukan oleh Zeithaml, et al. (1996) menunjukkan bahwa kualitas layanan telah terbukti menjadi prediktor niat untuk mengulangi perilaku. Berikut adalah hipotesis yang kami ajukan:

H9. Kualitas layanan berpengaruh secara signifikan terhadap minat untuk melanjutkan menggunakan SIPP online

\section{METODE}

Jenis penelitian ini adalah penelitian kuantitatif menggunakan teknik analisis Structural Equation Modeling (SEM) untuk memvalidasi hubungan kausal antara variabel dengan software SmartPLS. PLS-SEM sangat sesuai untuk penelitian ini, karena PLS-SEM memiliki kemampuan untuk menggunakan pemodelan jalur untuk membangun hubungan kausal dan merupakan metode untuk mengumpulkan data dengan ukuran sampel yang relatif kecil (Lin \& Filieri, 2015). Populasi penelitian adalah perusahaan peserta BPJS 
Ketenagakerjaan pengguna SIPP online di salah satu cabang BPJS Ketenagakerjaan di kota Surabaya dengan segmentasi perusahaan Platinum dan Gold. Metode pemilihan sampel pada penelitian ini menggunakan probability sampling dengan teknik simple random sampling. Jumlah sampel ditentukan dengan menggunakan rumus Slovin sebagai berikut:

$n=\frac{N}{1+N(e)^{2}}$

Di mana $\mathrm{n}$ adalah jumlah sampel, $\mathrm{N}$ merupakan ukuran populasi, dan e merupakan persentase kesalahan dalam pengambilan sampel yang masih bisa ditolelir. Berdasarkan rumus di atas maka diperoleh sampel penelitian sebanyak 50 perusahaan.

$n=\frac{N}{1+N(e)^{2}}=\frac{100}{1+100(0,1)^{2}}=50$

Pengumpulan data dilakukan melalui online kuesioner, yaitu dengan membagikan link kuesioner melalui email kepada kepala HRD perusahaan peserta pengguna SIPP online. Kuesioner menggunakan 5 poin skala Likert (1= Sangat Tidak Setuju; 5 = Sangat Setuju). Pengambilan kuesioner dilakukan pada bulan Januari - Maret 2016. Kuesioner yang dibagikan kepada responden dibagi menjadi dua bagian, yaitu: (1) Karakteristik responden (untuk mengetahui karakteristik dari responden, yaitu segmentasi perusahaan), (2) Variabel penelitian (untuk mengetahui jawaban responden terhadap variabel-variabel yang digunakan pada penelitian). Terdapat total 34 item yang digunakan untuk mengukur konstrukkonstruk dalam penelitian ini. Tabel 1 berikut menyajikan karakteristik responden. Berdasarkan Tabel 1 dapat diketahui bahwa mayoritas responden dalam sampel kami (86\%) merupakan perusahaan dengan segmentasi Gold, sedangkan sisanya (14\%) berasal dari segmentasi Platinum.

Tabel 1. Deskripsi Responden

\begin{tabular}{ccc}
\hline Segmentasi & Frekuensi & Presentase $(\%)$ \\
\hline Platinum & 7 & 14 \\
Gold & 43 & 86 \\
\hline Total & 50 & 100 \\
\hline
\end{tabular}

\section{HASIL DAN PEMBAHASAN}

Model diuji dengan dua tahapan, yaitu pengujian uji measurement model dan uji structural model untuk memastikan bahwa model yang digunakan dalam penelitian memenuhi persyaratan yang tentukan.

\section{Uji Measurement Model}

Uji validitas dilakukan dengan melihat loading factor setiap indikator terhadap konstruk. dengan ketentuan bahwa jika nilai loading factor lebih dari 0,7 maka dianggap telah memenuhi persyaratan dan dapat dipergunakan di dalam uji selanjutnya (Hair, Ringle, \& Sarstedt, 2011). Berdasarkan kriteria ini maka indikator dari konstruk $\times 2$ (perceived ease of use) yaitu X21, X23, X25, X27 kita drop (buang) karena memiliki loading factor di bawah 0,7. Hasil uji validitas untuk seluruh indikator konstruk setelah dilakukan pemodelan ulang adalah sebagaimana pada Tabel 2. Indikator konstruk berdasarkan nilai loading factor seluruhnya dinyatakan valid, sehingga seluruh indikator dapat dipergunakan dalam uji selanjutnya.

Discriminant validity dipergunakan untuk menguji indikator reflektif. Indikator reflektif dinyatakan valid jika cross loading terhadap 
Tabel 2. Tabel Uji Validitas Indikator

\begin{tabular}{|c|c|c|c|}
\hline Konstruk & Pernyataan & Loading Factor & Keterangan \\
\hline \multirow{10}{*}{$\begin{array}{l}\text { Perceived } \\
\text { Usefulness } \\
\qquad\left(X_{1}\right)\end{array}$} & $\mathrm{X} 11$ & 0,749711 & Valid \\
\hline & $\mathrm{X} 12$ & 0,772858 & Valid \\
\hline & $\mathrm{X} 13$ & 0,811677 & Valid \\
\hline & X14 & 0,821911 & Valid \\
\hline & X15 & 0,9031 & Valid \\
\hline & $\mathrm{X} 16$ & 0,873804 & Valid \\
\hline & X17 & 0,81744 & Valid \\
\hline & $\mathrm{X} 18$ & 0,813144 & Valid \\
\hline & X19 & 0,879974 & Valid \\
\hline & $\mathrm{X} 110$ & 0,885535 & Valid \\
\hline \multirow{6}{*}{$\begin{array}{c}\text { Perceived } \\
\text { Ease of Use } \\
\left(\mathrm{X}_{2}\right)\end{array}$} & $\mathrm{X} 22$ & 0,777002 & Valid \\
\hline & X24 & 0,745415 & Valid \\
\hline & X26 & 0,856019 & Valid \\
\hline & X28 & 0,860773 & Valid \\
\hline & X29 & 0,881176 & Valid \\
\hline & $X 210$ & 0,865561 & Valid \\
\hline \multirow{3}{*}{$\begin{array}{c}\text { Kenyamanan } \\
\left(\mathrm{X}_{3}\right)\end{array}$} & X31 & 0,872784 & Valid \\
\hline & X32 & 0,918573 & Valid \\
\hline & X33 & 0,90714 & Valid \\
\hline \multirow{3}{*}{$\begin{array}{l}\text { Keamanan } \\
\left(\mathrm{X}_{4}\right)\end{array}$} & $X 41$ & 0,918084 & Valid \\
\hline & X42 & 0,925104 & Valid \\
\hline & $X 43$ & 0,937282 & Valid \\
\hline \multirow{5}{*}{$\begin{array}{l}\text { Kualitas } \\
\text { layanan (Z) }\end{array}$} & Z11 & 0,75439 & Valid \\
\hline & Z12 & 0,864718 & Valid \\
\hline & Z13 & 0,880123 & Valid \\
\hline & Z14 & 0,864185 & Valid \\
\hline & Z15 & 0,90357 & Valid \\
\hline Minat untuk & Y21 & 0,970404 & Valid \\
\hline melanjutkan & Y22 & 0,938322 & Valid \\
\hline$(Y)$ & Y23 & 0,923827 & Valid \\
\hline
\end{tabular}

konstruk lebih besar dibandingkan dengan cross loading terhadap konstruk yang lainnya dan nilai square root of average variance extracted(AVE) lebih dari 0,5 maka dinyatakan valid (Hair et al., 2011). Hasil uji discriminant validity untuk indikator reflektif variabel penelitian menunjukkan bahwa seluruh cross loading terhadap konstruknya lebih besar daripada terhadap konstruk yang lainnya. Di samping itu seluruh konstruk mempunyai nilai AVE lebih besar dari 0,5 sehingga validitas diskriminan terpenuhi (lihat Tabel 3).
Uji reliabilitas konstruk dengan melihat nilai composite reliability dan Cronbach Alpha indikator terhadap konstruk. Nilai yang disyaratkan untuk memenuhi reliabilitas adalah composite reliability 0,7 dan Cronbach's Alpha 0,7 (Hair et al., 2011). Hasilnya menunjukkan bahwa masingmasing konstruk sangat reliabel karena memiliki composite reliability dan Cronbach alpha lebih besar dari 0,7 (lihat Tabel 4). 
Tabel 3. Hasil uji square root of average variance extracted (AVE)

\begin{tabular}{lcc}
\hline & AVE & Keterangan \\
\hline Perceived Usefulness (X1) & 0,696079 & valid \\
Perceived Ease of Use (X2) & 0,693123 & valid \\
Kenyamanan (X3) & 0,809478 & valid \\
Keamanan (X4) & 0,859064 & valid \\
Kualitas layanan (Z) & 0,730942 & valid \\
Minat untuk melanjutkan (Y) & 0,891863 & valid \\
\hline
\end{tabular}

\section{Uji Structural Model}

Pengujian struktur model (inner model) dilakukan dengan melihat hasil nilai R Square pada setiap konstruk. Nilai R Square untuk kualitas layanan adalah $72,75 \%$, hal ini dapat diartikan bahwa konstruk kualitas layanan dapat dijelaskan oleh konstruk perceived usefulness, perceived ease of use, kenyamanan, dan keamanan sedangkan $27,25 \%$ dijelaskan oleh variabel lain di luar penelitian ini. Minat untuk melanjutkan memiliki R Square sebesar $67,82 \%$ hal ini dapat diintepretasikan bahwa perceived usefulness, perceived ease of use, kenyamanan, dan keamanan dalam membentuk minat melanjutkan melalui kualitas layanan yaitu sebesar 67,82\% sedangkan sisanya dijelaskan oleh faktorfaktor lain yang tidak diteliti dalam penelitian ini.

Uji Hipotesis dilakukan dengan membandingkan $t$ value dengan $t$ tabel, dengan acuan penilaian bahwa $t$ value lebih besar dari 1,96 (significance level = 5\%) maka pengaruh antar variabel adalah signifikan (Hair et al., 2011). Arah hubungan antar variabel dilihat dari nilai pada kolom Original Sample (O). Hasil menunjukkan bahwa hanya tiga hubungan yang signifikan yaitu PU ke minat melanjutkan, PEOU ke kualitas layanan, dan kenyamanan ke kualitas layanan.

Hipotesis pertama adalah pengaruh perceived usefulness (PU) terhadap kualitas layanan SIPP online menunjukkan PU bukan merupakan faktor yang signifikan untuk menentukan kualitas layanan yang dirasakan. Hal ini berbeda dengan penelitian Hu et al. (2009) yang menyatakan bahwa PU merupakan determinan dan prediktor kuat dari kualitas layanan. Studi ini berpendapat bahwa hasil yang mengejutkan ini bergantung pada variabel seperti interaksi personal dibandingkan dengan mesin. Walaupun sistem yang digunakan dirasakan dapat mempermudah untuk melakukan pelaporan data dan upah tenaga kerja, akan tetapi Yang, Liang, \& Wang (2010)

Tabel 4. Uji Reliabilitas dengan Composite Reliability

\begin{tabular}{ccc}
\hline & Composite Reliability & Cronbach Alpha \\
\hline X1 & 0,95803 & 0,95109 \\
X2 & 0,931041 & 0,910679 \\
X3 & 0,927221 & 0,882317 \\
X4 & 0,948146 & 0,918159 \\
Y & 0,961138 & 0,93914 \\
Z & 0,931196 & 0,906932 \\
\hline
\end{tabular}


Tabel 5. Hasil Pengujian Hipotesis

\begin{tabular}{cccc}
\hline Hipotesis & Path & $\begin{array}{c}\text { Original Sample } \\
(\mathrm{O})\end{array}$ & $\begin{array}{c}\text { T Statistics } \\
(\mid \text { O/STERR })\end{array}$ \\
\hline H1 & X1 -> Z & 0,176582 & 1,270238 \\
H2 & X1 -> Y & 0,683461 & 3,821495 \\
H3 & X2 -> Z & 0,394826 & 2,185532 \\
H4 & X2 -> Y & 0,190141 & 0,974783 \\
H5 & X3 -> Z & 0,356386 & 1,983157 \\
H6 & X3 -> Y & 0,061847 & 0,355994 \\
H7 & X4 -> Z & $-0,00028$ & 0,001391 \\
H8 & X4 -> Y & $-0,086114$ & 0,471235 \\
H9 & Z -> Y & $-0,133824$ & 0,548154 \\
\hline
\end{tabular}

mengemukakan bahwa interaksi personal dapat menjadi faktor penting untuk menentukan kualitas layanan yang dirasakan.

Hipotesis kedua adalah pengaruh perceived usefulness (PU) terhadap minat untuk melanjutkan menggunakan SIPP online menunjukkan bahwa PU memiliki peranan penting dalam mempengaruhi minat perusahaan untuk menggunakan kembali SIPP online. Hal ini dapat dijelaskan bahwa pelaporan online bisa dianggap lebih berguna daripada pelaporan manual dikarenakan perusahaan dapat menghemat waktu dikarenakan tidak perlu untuk mengisi banyak formulir cetak, pergi ke kantor cabang untuk melakukan pelaporan, dan melakukan antrian. Hasil ini juga sejalan dengan penelitian-penelitian terdahulu ( $\mathrm{Hu}$ et al., 2009; Lee \& Chen, 2014; Lin \& Filieri, 2015; Susanto, Chang, \& Ha, 2016).

Hipotesis ketiga adalah pengaruh perceived ease of use (PEOU) pada kualitas layanan menunjukkan bahwa kemudahan untuk menggunakan sistem dapat berpengaruh pada pengalaman layanan yang dirasakan. Agar pengguna dapat berhasil berinteraksi dengan layanan dan menyelesaikan tugas yang diperlukan, sistem yang ada harus mudah untuk digunakan dan informasi yang ada juga harus mudah diakses. Kemudahan ini dapat mengembangkan penilaian positif terhadap kualitas layanan SIPP online. Jika persepsi kemudahan rendah, maka pengguna tidak memiliki pengalaman layanan yang positif (Bhattacherjee \& Premkumar, 2004).

Hipotesis keempat adalah pengaruh perceived ease of use (PEOU) pada minat untuk melanjutkan. Inkonsisten dengan penelitian Lin \& Filieri (2015) dan Wangpipatwong, Chutimaskul, \& Papasratorn (2008), dalam penelitian ini PEOU bukan merupakan faktor yang signifikan untuk menentukan minat untuk melanjutkan penggunaan sistem pelaporan online. Hal ini sejalan dengan literatur yang ada bahwa kemudahan penggunaan yang dirasakan tidak memiliki dampak langsung yang signifikan terhadap minat melanjutkan penggunaan IT (Bhattacherjee, 2001; Venkatesh, Morris, Davis, \& Davis, 2003). Sistem dikembangkan atau dibuat dengan tujuan semakin mudah untuk digunakan. Hal ini menyebabkan pengguna hanya membutuhkan sedikit usaha agar dapat mengoperasikan sistem tersebut. Pengguna juga semakin terbiasa dengan pengoperasian 
sistem online setelah mengoperasikannya pertama kali, sehingga kemudahan penggunaan cenderung tidak menjadi fokus mereka. Oleh karena itu bahwa PEOU memiliki efek tidak signifikan terhadap minat melanjutkan dapat diterima (Hou, 2015; Yuan, Liu, Yao, \& Liu, 2014).

Hipotesis kelima adalah pengaruh kenyamanan terhadap kualitas layanan menunjukkan hasil signifikan. Hal ini sejalan dengan penelitian (Hu et al., 2009). Sistem online menawarkan fleksibilitas waktu dan usaha dalam menyelesaikan pekerjaan (Collier \& Kimes, 2012). Dalam hal pelaporan online, pengguna dapat melakukan perubahan data dan upah tenaga kerja kapan saja dan di mana saja dengan sistem yang dapat diakses sewaktu-waktu. Hal ini dapat menimbulkan kenyamanan bagi pengguna dan meningkatkan pengalaman layanan yang positif.

Hipotesis keenam adalah pengaruh kenyamanan terhadap minat untuk melanjutkan menunjukkan tidak terdapat hubungan antara kedua konstruk ini. Hal ini tidak sejalan dengan penelitian (Hu et al., 2009). Kenyamanan dalam penelitian ini bukan merupakan faktor signifikan untuk menentukan minat untuk melanjutkan penggunaan sistem pelaporan online. Walaupun sistem pelaporan online dapat dilakukan kapan saja dan di mana saja, kenyamanan dalam menggunakan teknologi tidak langsung berdampak pada minat untuk menggunakan, tapi kemudahan untuk menggunakan dan menyelesaikan pekerjaan dengan menggunakan sistem tersebut juga dapat mempengaruhi minat untuk menggunakan kembali (Ambali \& Bakar, 2014).
Hipotesis ketujuh adalah pengaruh keamanan terhadap kualitas layanan menunjukkan tidak terdapat hubungan antara kedua konstruk ini, berbeda dengan penelitian Hu et al. (2009) dan Zeithaml et al. (2002) yang menyatakan keamanan merupakan faktor penting dalam menentukan kualitas layanan. Hal ini dapat dijelaskan bahwa pada sistem pelaporan online ini, pengguna bertujuan untuk menyampaikan informasi tentang perubahan data dan upah tenaga kerja. Tidak ada transaksi finansial sebagaimana transaksi keuangan (misal: perbankan, belanja online) sehingga keamanan menjadi kurang penting bagi mereka. Jiang \& Ji (2014) dalam konteks adopsi e-Government mengemukakan bahwa dalam hal pertukaran informasi, tujuan utama pengguna bukan melakukan transaksi sehingga keamanan dianggap menjadi kurang penting.

Hipotesis kedelapan adalah pengaruh keamanan terhadap minat melanjutkan menunjukkan tidak terdapat hubungan antara kedua konstruk ini. Hal ini tidak konsisten dengan penelitian Pikkarainen, Pikkarainen, Karjaluoto, \& Pahnila (2004). Akan tetapi hal ini bisa saja disebabkan karena SIPP online ini merupakan bagian dari sistem pemerintah. Berbeda dengan sistem online pada sektor komersial, pemerintah dapat memaksa perusahaan untuk menggunakan aplikasi ini sehingga keamanan bukan merupakan isu kritis bagi pengguna (Jiang \& Ji, 2014).

Hipotesis kesembilan adalah pengaruh kualitas layanan terhadap minat melanjutkan menunjukkan tidak terdapat hubungan antara kedua konstruk ini. Hasil dalam 
penelitian ini tidak konsisten dengan penelitian Akter, Ray, \& D'Ambra (2013) dan Hu et al. (2009). Penelitian He \& Jun (2010) dan Huayong, Mian, Kaijun, \& Jinbo (2016) dalam konteks industri jasa mengemukakan bahwa kualitas layanan yang tinggi/rendah tidak menjamin konsumen beralih pada penyedia jasa lainnya. Hal ini mengindikasikan bahwa kualitas layanan memiliki efek terbatas pada pilihan konsumen. Walaupun kualitas layanan merupakan faktor penting dalam kesuksesan sistem online, akan tetapi Jiang \& Ji (2014) berpendapat bahwa dalam hal penggunaan sistem terkait dengan e-Government, pemerintah dapat mewajibkan perusahaan untuk menggunakan sistem tersebut (misalnya melalui formulir-formulir yang hanya dapat diunduh melalui Internet). Hal ini dapat menyebabkan kualitas layanan bukan faktor yang dominan dalam menentukan minat untuk menggunakan suatu sistem online.

\section{SIMPULAN}

Penelitian ini bertujuan untuk menganalisis faktor-faktor yang dapat berpengaruh pada kualitas layanan dan minat untuk melanjutkan kembali penggunaan SIPP online. Temuan dalam studi ini memberikan kontribusi pada literatur penerimaan teknologi informasi dalam konteks sistem online di sektor pemerintah. Hasil penelitian menunjukkan bahwa kualitas layanan dalam konteks penelitian ini hanya dipengaruhi oleh persepsi kemudahan dan kenyamanan menggunakan sistem. Sedangkan dalam hal minat untuk melanjutkan penggunaan sistem online hanya dipengaruhi oleh persepsi manfaat yang dirasakan pengguna.
Secara praktis, penelitian ini dapat bermanfaat bagi pengembang sistem online dalam mendesain dan mengembangkan aplikasi untuk sektor pemerintahan yang tentunya berbeda dengan sektor komersial. Keterbatasan penelitian ini adalah hanya dilakukan pada satu cabang di satu kota saja dengan jumlah responden yang tidak banyak. Penelitian selanjutnya dapat dilakukan pada beberapa cabang dan kota serta dengan melibatkan jumlah responden yang lebih banyak sehingga hasilnya dapat digeneralisasi.

\section{DAFTAR PUSTAKA}

Ahuja, M., Gupta, B., \& Raman, P. (2003). An Empirical Investigation of Online Consumer Purchasing Behavior. Communications of the ACM, 46(12), 145. http://doi.org/10.1145/953460.953494

Akter, S., Ray, P., \& D’Ambra, J. (2013). Continuance of mHealth services at the bottom of the pyramid: the roles of service quality and trust. Electronic Markets, 23(1), 29-47. http://doi.org/10.1007/s12525-0120091-5

Ambali, A. R., \& Bakar, A. N. (2014). ICT Adoption and Application in the Malaysian Public Sector. Hershey: IGI Publishing.

Berry, L. L., Seiders, K., \& Grewal, D. (2002). Understanding Service Convenience. Journal of Marketing, 66(3), 1-17.

Bhattacherjee, A. (2001). Understanding Information Systems Continuance: An Expectation-Confirmation Model. MIS Quarterly, 25(3), 351-370.

Bhattacherjee, A., \& Premkumar, G. (2004). Understanding Changes in Belief and Attitude toward Information Technology Usage: A Theoretical Model and 
Longitudinal Test. MIS Quarterly, 28(2), 229-254.

BPJS Ketenagakerjaan. (2016). Sistem Informasi Jaminan Sosial Tenaga Kerja (SIJSTK). Jakarta.

Chang, M.-Y., Chen, K., Pang, C., Chen, C.-M., \& Yen, D. C. (2013). A study on the effects of service convenience and service quality on maintenance revisit intentions. Computer Standards and Interfaces, 35, 187-194. http://doi.org/10.1016/j.csi.2012.08.002

Collier, J. E., \& Kimes, S. E. (2012). Only If It Is Convenient: Understanding How Convenience Influences Self-Service Technology Evaluation. Journal of Service Research, 16(1), 39-51. http://doi.org/10.1177/1094670512458 454

Curran, J. M., \& Meuter, M. L. (2005). Selfservice technology adoption: comparing three technologies. Journal of Services Marketing, 19(2), 103-113.

Davis, F. D. (1985). A technology acceptance model for empirically testing new enduser information systems: Theory and results. Management.

Hair, J. F., Ringle, C. M., \& Sarstedt, M. (2011). PLS-SEM: Indeed a Silver Bullet. The Journal of Marketing Theory and Practice, 19(2), 139-152. http://doi.org/10.2753/MTP10696679190202

He, G., \& Jun, L. (2010). Study of the Relationship Between Service Quality, Customer Satisfaction and Behavior Intention. In International Conference on E-Product E-Service and E-Entertainment (ICEEE) (pp. 1-4). Henan, China: IEEE.

Hidayat-ur-rehman, I., Mokhtar, S. A., \& Katan, H. (2016). An Empirical Analysis of Consumers' Continuance Intention Towards Online Shopping. Mediterranean Journal of Social Sciences,
7(5),

95-104. http://doi.org/10.5901/mjss.2016.v7n5p 95

Hou, C.-K. (2015). Understanding Business Intelligence System Continuance Intention: An Empirical Study of Taiwan's Electronics Industry. Information Development, 1-13. http://doi.org/10.1177/0266666915599 588

Hu, P. J., Brown, S. A., Thong, J. Y. L., Chan, F. K. Y., \& Tam, K. Y. (2009). Determinants of Service Quality and Continuance Intention of Online Services: The Case of eTax. Journal of American Society for Information Science and Technology, 60(2), 292-306. http://doi.org/10.1002/asi

Huayong, D., Mian, Z., Kaijun, L., \& Jinbo, C. (2016). Examining the Role of Inhibitors in Customer Intention to Continue Using Mobile Services: An IS Success Theory Perspective. Recent Patents on Computer Science, 9(3).

Jarvenpaa, S. L., \& Todd, P. A. (1996). Consumer Reactions to Electronic Shopping on the World Wide Web. International Journal of Electronic Commerce, 1(2), 59-88.

Jiang, X., \& Ji, S. (2014). E-Government web portal adoption: A service level and service quality perspective. In Proceedings of the Annual Hawaii International Conference on System Sciences (pp. 2179-2188). IEEE. http://doi.org/10.1109/HICSS.2014.275

Lee, H. M., \& Chen, T. (2014). Perceived quality as a key antecedent in continuance intention on mobile. International Journal of Electronic Commerce Studies, 5(2), 123-142. http://doi.org/10.7903/ijecs.1150

Lin, Z., \& Filieri, R. (2015). Airline passengers' continuance intention towards online check-in services: The role of personal 
innovativeness and subjective knowledge. Transportation Research Part E, 81, 158-168. http://doi.org/10.1016/j.tre.2015.07.00 1

Miyazaki, A. D., \& Fernandez, A. (2001). Consumer Perceptions of Privacy and Security Risks for Online Shopping. The Journal of Consumer Affairs, 35(1), 2744.

Parasuraman, A., Zeithaml, V. A., \& Berry, L. L. (1988). SERVQUAL: A Multiple-Item Scale for Measuring Consumer Perceptions of Service Quality. Journal of Retailing, 64(1), 12-40.

Pikkarainen, T., Pikkarainen, K., Karjaluoto, H., \& Pahnila, S. (2004). Consumer acceptance of online banking: an extension of the technology acceptance model. Internet Research, 14(3), 224235.

http://doi.org/https://doi.org/10.1108/1 0662240410542652

Rai, A., Lang, S. S., \& Welker, R. B. (2002). Assessing the Validity of IS Success Models: An Empirical Test and Theoretical Analysis. Information Systems Research, 13(1), 50-69.

Susanto, A., Chang, Y., \& Ha, Y. (2016). Determinants of continuance intention to use the smartphone banking services. Industrial Management \& Data Systems, 116(3), 508-525.

Torkzadeh, G., \& Dhillon, G. (2002). Measuring factors that influence the success of Internet commerce. Information Systems Research, 13(2), 187-204.

http://doi.org/10.1287/isre.13.2.187.87

Venkatesh, V., Morris, M. G., Davis, G. B., \& Davis, F. D. (2003). User Acceptance of Information Technology: Toward a Unified View. MIS Quarterly, 27(3), 425478.
Vijayasarathy, L. R. (2004). Predicting consumer intentions to use on-line shopping: the case for an augmented technology acceptance model. Information \& Management 41, 41, 747762.

http://doi.org/10.1016/j.im.2003.08.011

Wangpipatwong, S., Chutimaskul, W., \& Papasratorn, B. (2008). Understanding Citizen's Continuance Intention to Use eGovernment Website: a Composite View of Technology Acceptance Model. The Electronic Journal of E-Government, 6(1), 55-64.

Wu, X., Chen, Q., Sheng, L., \& Wang, Y. (2009). A conceptual model of $\mathrm{m}$ commerce customers' continuance intention based on the customers' perceived value. International Journal of Mobile Learning and Organisation, 3(3), 243-257.

http://doi.org/10.1504/IJMLO.2009.026 311

Yang, K., Liang, H., \& Wang, B. (2010). Studies on the Factors of Interaction Quality in Public Service Quality Management. In International Conference on Management and Service Science (MASS 2010). Wuhan, China: IEEE.

Yuan, S., Liu, Y., Yao, R., \& Liu, J. (2014). An investigation of users' continuance intention towards mobile banking in China. Information Development, 1-15. http://doi.org/10.1177/0266666914522 140

Zeithaml, V. A., Berry, L. L., \& Parasuraman, A. (1996). The behavioral consequences of service quality. Journal of Marketing, $60,31-46$.

Zeithaml, V. A., Parasuraman, A., \& Malhotra, A. (2002). Service Quality Delivery through Web Sites: A Critical Review of Extant Knowledge. Journal of the Academy of Marketing Science, 30(4), 362-375. 
Jurnal Economia, Volume 13, Nomor 2, Oktober 2017

Zhang, X., \& Prybutok, V. (2005). A Consumer Perspective of E-Service Quality. IEEE Transactions on Engineering Management, 52(4), 461-477.

Zhao, L., Lu, Y., Zhang, L., \& Chau, P. Y. K. (2012). Assessing the effects of service quality and justice on customer satisfaction and the continuance intention of mobile value-added services: An empirical test of a multidimensional model. Decision Support Systems, 52, 645-656. http://doi.org/10.1016/j.dss.2011.10.02 2 